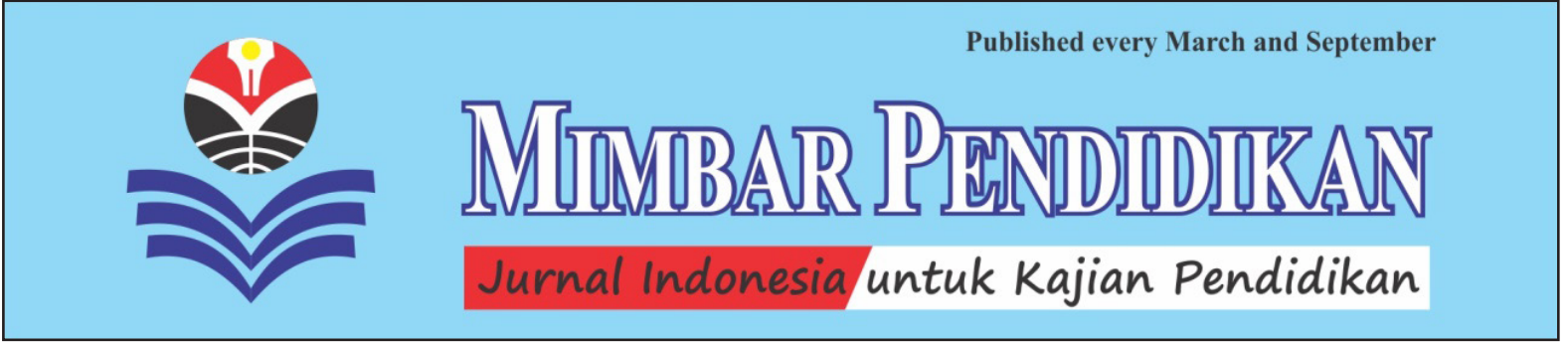

SUSANTI

\title{
The Use of WhatsApp in Reading Lesson at the STMIK Pontianak, West Kalimantan, Indonesia
}

\begin{abstract}
The aim of this study is to figure out the effects of WhatsApp mobile learning in teaching reading to students in the $2^{\text {nd }}$ semester of Informatics Technique Program at the STMIK (College of Computer Science Management) Pontianak, West Kalimantan, Indonesia. Experimental study is the research design applied to figure out more the effect of WhatsApp usage by the learners in reading lesson. The classes are grouped into experimental and control groups. Students in experimental group have additional learning activities, besides the normal class in the classroom, that is additional learning using WhatsApp mobile learning; but students in control group just have the normal class as usual in the classroom. Questionaires, WhatsApp platforms, and Pre-post tests become the sources of data collection used. The results indicated that WhatsApp mobile learning usage in learning reading skill to the $2^{\text {nd }}$ semester students of Informatics Technique Program at the STMIK Pontianak shows an insignificant results of this study. So, it is needed to support from other institutions for the ease and decent WiFi (Wireless Fidelity) access for using WhatsApp in mobile phone assisted learning.

KEY WORD: Mobile Phone Assisted Learning; Reading Lesson; Using WhatsApp.
\end{abstract}

ABSTRAKSI: "Penggunaan WhatsApp dalam Pelajaran Membaca di STMIK Pontianak, Kalimantan Barat, Indonesia". Tujuan dari penelitian ini adalah untuk mengetahui pengaruh aplikasi "WhatsApp" pada telefon genggam didalam pembelajaran membaca pada mahasiswa Program Teknik Informatika semester 2 di STMIK (Sekolah Tinggi Manajemen Ilmu Komputer) Pontianak. Studi eksperimen adalah desain penelitian yang digunakan untuk mengetahui lebih jauh pengaruh penggunaan "WhatsApp" oleh para mahasiswa dalam pelajaran membaca. Kelas dikelompokkan menjadi kelas eksperimen dan kelas kontrol. Para mahasiswa di kelas eksperimen mempunyai aktivitas belajar tambahan, selain belajar rutin di kelas, yaitu tambahan belajar menggunakan aplikasi "WhatsApp" pada telefon genggam; tetapi para mahasiswa di kelas kontrol hanya belajar seperti pada umumnya didalam kelas. Kuestioner, program "WhatsApp", dan pra-pasca tes menjadi sumber pengumpulan data. Hasil penelitian menunjukkan bahwa penggunaan "WhatsApp" pada telefon genggam dalam pembelajaran keterampilan membaca pada mahasiswa semester 2 Program Teknik Informatika di STMIK Pontianak menunjukkan hasil yang tidak memuaskan. Jadi, diperlukan dukungan dari lembaga lain untuk kemudahan dan akses WiFi (Jaringan Internet) untuk menggunakan "WhatsApp" dalam pembelajaran berbantukan telefon genggam.

KATA KUNCI: Pembelajaran Berbantukan Telefon Genggam; Pelajaran Membaca; Penggunaan "WhatsApp".

About the Author: Susanti, M.Pd. is a Lecturer of Information System at the STMIK (Sekolah Tinggi Manajemen Ilmu Komputer or College of Computer Science Management) Pontianak, Jalan Merdeka Barat No.372, Kota Pontianak, West Kalimantan, Indonesia. For academic interests, the Author is able to be contacted via e-mail address at: santy.mayfoura@gmail.com

Suggested Citation: Susanti. (2020). "The Use of WhatsApp in Reading Lesson at the STMIK Pontianak, West Kalimantan, Indonesia" in MIMBAR PENDIDIKAN: Jurnal Indonesia untuk Kajian Pendidikan, Volume 5(1), March, pp.57-74. Bandung, Indonesia: UPI [Indonesia University of Education] Press, ISSN 2527-3868 (print) and 2503-457X (online).

Article Timeline: Accepted (January 9, 2020); Revised (February 28, 2020); and Published (March 30, 2020). 


\section{INTRODUCTION}

Recently, mobile phones as precious thing to be owned by most people in the world, than gold. Many things can be learned or done by people using the mobile phones. The MALL (Mobile Assisted Language Learning) is one of the most interesting emerging types of technology enhanced learning, especially now that mobile devices are carried by more and more people every day; and the mobile phones has evolved from a simple voice device to a multimedia communications tool capable of downloading and uploading text, data, audio, and video - from text messages to social network updates to breaking news, the latest hit songs, as well as an alarm clock, calculator, address book, newspaper, and cameras (Chinnery, 2006; Kelly \& Minges, 2011; Motteram, 2013:59; Yudhiantara \& Nasir, 2017; and Ahmadi, 2018).

Then, this combination of available applications and a device that learners usually carry offers an opportunity to introduce learners to tools for study, which could help them in later life, as well as new motivating ways of learning a language. Most importantly, however, mobile technology allows for a situated learning approach, because learning can take place in the student's actual work environment (Eady \& Lockyer, 2013; Motteram, 2013; and Ahmadi, 2018).

It is also evident that there is now a new generation of children, whom the literature calls "Digital Children" and the "Network Generation", who are surrounded by media and information technologies that include internet, smartphones, and the social media in general (Prensky, 2001; Roman, 2016:255; and Long, 2018). Of all the technological means noted above, the WhatsApp has become one of the most popular in the market, as evident from its usage by over 350 million users (Tzuk, 2013; Bouhnik \& Deshen, 2014; and Roman, 2016).
WhatsApp is a smartphone app intended for sending instant messages. Messages can be sent both personally and in group form - such that it is possible to communicate with several people simultaneously. Next, people utilize this app, due to its low cost; the immediate possibility of holding a fluent conversation; the sense of belonging to a group that creates a feeling of community and family; and the confidentiality maintained, unlike social media networks (Church \& de Oliveira, 2013; Bouhnik \& Deshen, 2014; and Roman, 2016).

According to D.B. Deshen et al. (2014), and other scholars, this app has academic benefits that are manifested in the teacher's availability for study questions and possibility of sending study material by WhatsApp, such that it reaches everyone immediately. Notably, use of WAG (WhatsApp Group) also enables the students to review the material at home, and to bring additional knowledge beyond the official hours (Bouhnik \& Deshen, 2014; Deshen et al., 2014; and Roman, 2016).

Moreover, teacher can correct students mistakes on the spot and offer comments. As stated, it is evident that due to use of WAG, students feel a sense of confidence that they have an address for any question or request they may have. Furthermore, WhatsApp enables communication with anyone who possesses a smartphone; has an active internet connection; and has installed the application. The overall cost of the application is very low, up to one USA (United States of America) Dollar per year (Bouhnik \& Deshen, 2014; Roman, 2016:255; and Zuo, 2017).

Next, one of the application's unique features is the option to create a group and to communicate within its boundaries. Moreover, the creator of the group becomes its manager, a position that includes the privilege of adding and removing participants without the need for approval from the group members (Bouhnik \& 
Deshen, 2014; Deshen et al. 2014:218-219; and Kolzow, 2014).

There are two benefits of WhatsApp for distance learning: mobile learning and context free access to learning resources. Student appropriation of WhatsApp enabled phones for lecturer-students and peer-based consultation leveraged their participation as they redressed poor connectivity via institutional networks. Device portability coupled with affordances for anywhere and anytime access to information and learning resources redressed the constraints distance, space, and temporal times is access to internet (Amry, 2014; Susilo, 2014:21; and Barhoumi, 2015).

Next, A. Susilo (2014), and other scholars, added more that WhatsAppmediated learning's support for multiple access to learning resources imparted students' ability to engage with peers and tutor synchronously. Then, WhatsApp's affordances for a synchronous communication also directly impacted student participation. Students believed that WhatsApp discussion forum allowed them to reflect "deeply" on questions before giving their opinions ( $c f$ Susilo, 2014:21; Alfelaij, 2015; and Willemse \& Bozalek, 2015).

Meanwhile, Z. Onat-Stelma, D. Slaouti \& G. Motteram (2013), and other scholars, maintained that WhatsApp, Skype, and Go SMS (Short Message Service) pro are the commonly used social network applications among students in learning, in many of the developed nations; and WhatsApp being the leading (Onat-Stelma, Slaouti \& Motteram, 2013; Susilo, 2014; Mhandeni, 2016:72; and Ayuningtyas, 2018). Otherwise, WhatsApp mobile learning tool is still new for some people in developing countries, such as Indonesia. Moreover, WhatsApp became the new trend since 2016, nevertheless they just used this tool for sending instant messages, send funny videos, send photos, etc, without learning English aspects involved (Susilo, 2014; Felix, Rauschnabel \& Hinsch, 2016; and Ayuningtyas, 2018).

However, the use of these tools, to a large extend, is not in learning. It is rarely, or even never, be used for formal and informal learning by students, instructors, parents, and people, who responsible in education. One of the technological tools that has been so influential among the instructors and their students is WhatsApp. However, little is known regarding this social networking site in teaching and learning (Beldarrain, 2006; Fattah, 2015:117; and Mhandeni, 2016:73).

So, the most recent popular social network is WhatsApp application.

WhatsApp allows its users to use their internet connection to send messages to each other, it is like a chat program for mobile phones, and WhatsApp is available for almost all smart phones. In this context, P. Rambe \& C. Chipunza (2013), and other scholars, showed that students felt WhatsApp gave them the possibility to express themselves freely in a non-restricted environment; thus, removing the low participation constraints characteristics of lecturers (Rambe \& Chipunza, 2013; Fattah, 2015:120; and Mhandeni, 2016).

WhatsApp has spread mostly among young people who are students; and use it as an entertainment and funny tool. They largely depend on it to know a lot of news around the world. Besides, they may help them in their learning through exchanging information needed in learning English language, since it is used by most of the students. It provides access to learning resources, when teachers and students are separated by time and distance (Honeyman \& Miller, 1993; Amry, 2014; and Ta'ammeh, 2017:15).

There is also an emerging evidence that these WhatsApps have a significant potential to support the learning process and has substantial implications on pedagogies; allowing direct access to lots of online resources; and more focus on student's creativity, autonomy, and responsibility 
on one's own learning. Language learners have a more opportunity to listen and speak that language in their classroom with their friends and teacher; while they are not, they can extend their communication by connecting the application in their phones freely (Ifenthaler \& Schweinbenz, 2016; Mhandeni, 2016; and Hanisi et al., 2018:31).

In this study, researcher attempts to blend the use of WhatsApp mobile learning tool in teaching and learning for the supplementary activity out of class as the experimental group to see the effectiveness of this learning tool in enhancing students achievement. Next, the class which just have the normal class or face to face classroom interaction without WhatsApp mobile learning assisted, as the control group. This research conducted as the solution to some obstacles, such as the limited time to study; a big sized classes; problem with the LCD (Liquid Crystal Display) or computer; and the problem with the reading itself, such as lack of vocabulary, ambiquies, and unclear comprehension to reading text.

The research questions in this study are as follows: (1) How does WhatsApp mobile learning tool improve students' reading achievement and students' attitude toward learning?; and (2) Why do the students assisted in learning reading through WhatsApp mobile learning?

Mobile phones, and other smart devices, are perfect for developing mobile assisted language learning. Mobile devices are used at universities and higher educational institutions to enhance online interaction through discussion and to share knowledge between students. The mobile learning technology helps students to create a learning community, to easily construct knowledge, and to share it with other members of a WAG (WhatsApp Group) through instant messaging (Amry, 2014:133; Hanisi et al., 2018; and Ozer \& Kilic, 2018). Many insightful and updated information

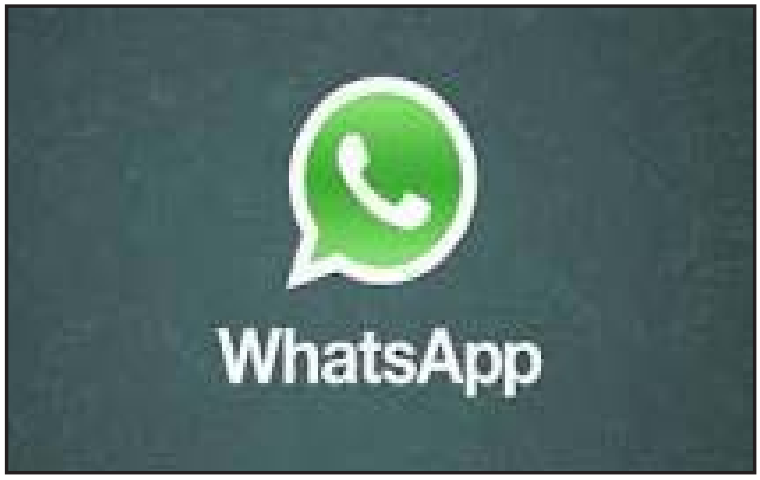

Figure 1:

WhatsApp Icon

and knowledge be provided and elaborated in some websites, such as at web.2.0, website of http://learnenglishbritishcouncil. org/en/apps (10/7/2019), and some others interesting and insightful webs, which will be helpful for beginners and other levels learners to learn English at anytime and anywhere, formal and informal situation (Motteram, 2013; Pim, 2013; and Akhmad $\&$ Amiri, 2018). All the vary and essential information preceding can be accessed through WhatsApp mobile learning as the right forum for discussing and sharing for learners and teachers. See figure 1.

WhatsApp instant messaging is a cross-platform smartphone messenger that employs users' existing internet data plan to help them network socially in real time. WhatsApp provides online users with the ability to send and receive a variety of media, such as images, videos, and audio media messages. WhatsApp is a free messenger app that works across multiple platforms, like iphone and android phones; and this application is being widely used among students to send multimedia messages, like photos, videos, and audios along with simple text messages (Amry, 2014; Bouhnik \& Deshen, 2014; and Rawekar, 2017:19).

According to A. Bere (2013), as cited also in S.G. Rawekar (2017), WhatsApp messenger has the following collaborative 
features: (1) Multimedia, it allows the users to exchange videos, text messages, images, and voice notes; (2) Group Chat, it supports the interaction of up to 50-256 group members; (3) Unlimited Messaging, the number of messages can share on WhatsApp is unlimited, the application uses 3G/EDGE internet data plan or Wi-Fi to ensure continuous data transmission across platforms; (4) Cross Platform Engagement, interactions with different devices can message one another through various media; (5) No Charger Involved, there is no charges involved for using WhatsApp as it uses same internet data plan, which is used for email or web browsing; and (6) Pins and Users Name, WhatsApp users need not to remember passwords or username as it works via phone numbers, and integrates with users address books ( $c f$ Bere, 2013; Bouhnik \& Deshen, 2014; and Rawekar, 2017:19).

The previous study stated that teaching large classes interactively has always been posing great challenges to language teachers in many of the developing countries. Also, instructors are recommended to adapt the tool synchronously in their courses, because the tool is effective at creative interactive learning environment (Arkorful \& Abaidoo, 2014; Mhandeni, 2016:73; and Aoumeur, 2017).

Other previous study also added that previous study have found that class WAG (WhatsApp Groups) are used for communicating with students; nurturing a social atmosphere in class; forming a dialoque and collaboration between the students; and as a means of learning, the possibility gives teacher to become more familiar with the students; and to influence students discourse, moreover, WhatsApp has academic benefits evident in the availability of the teacher, learning that continuous outside the classroom, and rapid access to study material (Amry, 2014; Bouhnik \& Deshen, 2014; and Roman, 2016).

Next, the interview done also show that the use of WhatsApp is preferable to other media, i.e. e-mail, FB (Face Book), and texting; and stressing the easy operation of the app, the lack of costs, and the privacy maintained in the group (cf Susilo, 2014; Roman, 2016:255; and Isaac, 2019). Furthermore, high infiltration of smartphones has initiated growing use of WhatsApp for groups of teachers and their students to support the learning process by allowing direct access to lots of online resources. Combination of medium, like videos, pictures voice notes, along with constant availability of facilitator and learning anytime and anywhere, has made WhatsApp a new and convenient tool for teaching learning activity (Amry, 2014; Bouhnik \& Deshen, 2014; Rawekar, 2017:24; and Hanisi et al., 2018).

The next previous study cited that an examination of the use of WhatsApp in a South African university class registered positive feedback from students, who claimed that it was an easier way to communicate with their teachers at the rest of the class, that it was productive of fruitful discourse on relevant issues in an informal environment where students could learn intimately and authentically, and that it was also fun. Overall, WhatsApp has become a shared platform that enhances accessibility, encourages cooperation, and intensifiers motivation to take an active part in academic assignments (cf Deshen et al., 2014; Gasaymeh, 2017; and Lediga, 2017).

Meanwhile, A. Susilo (2014), and other scholars, added more that WhatsApp was adopted for an information technology course at a South African university with a view to heighten lecturer-students and peer based participation; and enhance pedagogical delivery and inclusive learning informal or lectures and informal spaces (Susilo, 2014; Kilfoil ed., 2015; and Chawinga, 2017).

In his research, M.A. Ta'ammeh (2017)'s findings indicated that the experimental 
group that used a combination method (WhatsApp and traditional) was better than the control group, which was learned through the traditional method (face by face). Then, it can be concluded that English lesson can be learned more effectively through integrating technological applications, such as WhatsApp messenger in learning English than the traditional methods (cf Ta'ammeh, 2017:21; Minalla, 2018; and Wijayanti \& Gunawan, 2018).

K. Church \& R. de Oliveira (2013), and other scholars, have listed out the following reasons why people adopt WhatsApp as a tool for communication rather than other channels, such as SMS (Short Message Servive) or Messenger: the low cost of the application combined with the ability to send messages without any word restriction; time taken to reach a message to the recipient is very less; the desire to feel a part of the trend since their acquaintances have already adopted the application; the capacity to conduct an ongoing conversation among friends simultaneously; the knitting together of the kinship circle; and a sense of privacy to other social networks (Church \& de Oliveira, 2013; Bouhnik \& Deshen, 2014; and Sam, 2016).

In the current day situation, technology comes handy to overcome most of the limitations in terms of communication among students and between students and teachers. The use of internet technology by online learning communities may provide learning resources in synchronous or asynchronous mode. According to scholars' study, WhatsApp serves as an effective mode for students to continue learning beyond the classroom context. Then, it helps to be connected with the peers and teachers in the course of learning process outside the classroom ( $c f$ Zengin, Arikan \& Dogan, 2011; Amry, 2014; and Sam, 2016).

The following are the pedagogical implications using WhatsApp as an informal channel for learning: (1) Learning takes place within and without the classroom at the time and space comfortable for the students; (2) In the course of learning outside the classroom, students participate in a SOLE, or Self Organized Learning Environment, where they learn in their own pace and they collaborate with the peers online via WhatsApp; (3) While exploring content on a particular topic or an idea, students collaborate via WhatsApp with the peers and teachers; (4) Students not only surf the internet for information, but also share them with the peers instantly using WhatsApp, the information being shared need not be of any fixed format but of different format, such as audio files, video files, images, animation, and so on; (5) Students design learning strategies on their own in course of exploring materials/ contents outside the classroom context; (6) Students verify their ideas and information they have accumulated with the teachers outside the classroom via WhatsApp; (7) Teacher administer activities to students via WhatsApp groups and give individual feedback to students; and (8) Teacher could give individual feedback to students after the class hours via WhatsApp (Amry, 2014; Susilo, 2014; and Sam, 2016).

Next, S.F. Fattah (2015), and other scholars, recommended that we should make use of modern technology in teaching our students and we should part of this technology. In the past, it was difficult to communicate with our students, especially after the class, yet increasing advanced in technology teachers can communicate with their students through these application (WhatsApp), also it may be used as additional means for setting home assignment. Next, adopting WhatsApp application in teaching other skills like listening and speaking through exchanging files between students and teachers (Fattah, 2015:126; Sung, Chang \& Liu, 2016; and Ahmadi, 2018).

Lastly, M.M. Hamad (2017), and other scholars, in their study, besides the 
Table 1:

Means and Standard Deviation of Students' Scores on Pre-Test

\begin{tabular}{cccc}
\hline Method & & Control Group & Experimental Group \\
\hline \multirow{2}{*}{ Pre-Test } & Mean & 48.8181 & 49.8787 \\
& $\mathrm{~N}$ & 33 & 33 \\
& Std. Deviation & 93.4059 & 95.1974 \\
\hline
\end{tabular}

Table 2:

Means and Standard Deviation of Students' Scores on the Pre-Test and Post-Test

\begin{tabular}{cccc}
\hline Method & & Control Group & Experimental Group \\
\hline \multirow{3}{*}{ Control Group } & Mean & 48.8181 & 49.8787 \\
& $\mathrm{~N}$ & 33 & 33 \\
& Std. Deviation & 93.4059 & 95.1974 \\
\hline \multirow{2}{*}{ Experimental Group } & Mean & 61.1818 & 62.7575 \\
& $\mathrm{~N}$ & 33 & 33 \\
& Std. Deviation & 38.9972 & 19.1533 \\
\hline
\end{tabular}

advantages of WhatsApp in learning, there are also some disadvantages of WhatsApp in learning, such as: (1) Preparing material needs time and experience about software that support the Apps; (2) Students are not fixed to the agreed time, and they send messages in anytime, even if it is late night; (3) Some students don't participate in discussion; (4) Students' attention can't be assured, that not all students learn from the materials; (5) Some students just copy and paste; and (6) Instructor must be always cautious and patient to control the group (Faizi, el-Afia \& Chiheb, 2013; Gon \& Rawekar, 2017; and Hamad, 2017:85).

\section{METHODS}

This is an experimental research design, which one class was taught as normal class with WhatsApp assisted in learning out class, as the experimental group; and one other more class taught as normal class too, but without WhatsApp assisted in learning out class, as the control group. One of the group, the experimental group will receive a supplementary activity out the class, and one other group may not have the other supplementary activity out of class ( $c f$ Knight, 2010; Creswell, 2012; and Wardani \& Djukri, 2019).
In an experiment, the researcher will test an idea, here the use of WhatsApp mobile learning in teaching reading to students to determine, whether it influences an outcome or dependent variable, student readings' skill. So, the researcher firstly decides an idea to experiment, the use of WhatsApp mobile learning; and then determine whether those who experienced the idea at the STMIK (Sekolah Tinggi Manajemen Ilmu Komputer or College of Computer Science Management) students in Pontianak, West Kalimantan, Indonesia; performed better on some outcomes than those who did not experienced it, the control group (Knight, 2010; Creswell, 2012; and Amry, 2014).

To know the equivalency of students on the pre-test of both groups, then, the means and standard deviations were computed as shown in table 1 . The purpose of this action is to identify the level of each group and the results indicates that level of the students in both group are almost the same ( $c f$ Creswell, 2012; Sung, Chang \& Liu, 2016; and Ta'ammeh, 2017:21). See again table 1.

Besides, the table 2 of Means and Standard Deviation of pre-test, the Means and Standard Deviation of posttest also described to figure out the effect of WhatsApp to students in reading. 
Table 3:

Reading Scoring Rubric

\begin{tabular}{|c|c|c|}
\hline No. & Aspects & Scores \\
\hline 1. & Grammar & \\
\hline 2. & Vocabulary & \\
\hline 3. & Graphology & \\
\hline 4. & Contents & \\
\hline
\end{tabular}

Source: Pandiya (2013:48).

It indicates that the use of WhatsApp in learning, especially reading skill, is not significantly effect the students' achievement; and attitudes toward reading skill as delineated in the formula:

$$
\begin{gathered}
\bar{x}=\frac{\sum x}{n} \\
\mathrm{SD}=\sum\left(x i-\frac{\pi}{n}\right) 2
\end{gathered}
$$

The qualitative and quantitative data are analyzed, but the quantitative one is the best to be discussed (Onwuegbuzie \& Combs, 2011; Creswell, 2012; and Aspers \& Corte, 2019). Students of STMIK (Sekolah Tinggi Manajemen Ilmu Komputer or College of Computer Science Management) Pontianak, class 2-C1 and 2-C2, will have the same material in learning in the classroom. The different is class 2-C1 have WhatsApp mobile learning assisted to continue the lesson out of class; nevertheless class 2-C2 have no WhatsApp mobile learning assisted out the class.

Before starting the online WhatsApp section, the students of class 2-C1 have to register to be the members of WAG (WhatsApp Group) to their lecturer; then, the online WhatsApp teaching and learning may proceed. There are some activities can be uploaded or sent to this WhatsApp tool of learning, such as videos, texts, questions, quizzes, pictures, video call, etc. Students and teacher may interact at anytime and anywhere as the agreement, and the students' privacy is secured.

Teacher may access the learning material from some resources through internet provided or from the module provided by universities, or from some webs. As we know this web provide many insightful and interesting topics to learn, such as text about "Elephant Learn to Work Together"; "Why Do People Migrate"; "Ice Cream"; "Technology"; "ICT [Information and Communication Technology] in Learning"; and "Business and Work" provided in text and videos, with exercises attached.

Teacher may also prepare and deliver the vary topics of learning, as stated above, in teaching and learning in the classroom in normal learning, and followed by giving some written exercises to assess their comprehension to the lesson delivered in that meeting, both for experimental and control group, as the quantitative data. Nevertheless, the lesson will be continued, discussed, and elaborated by lecturer and students out the class for the experimental group using WhatsApp mobile learning (cf Sung, Chang \& Liu, 2016; Ozer \& Kilic, 2018; and Darling-Hammond et al., 2019).

The results of students platforms in WhatsApp mobile learning will be assessed for the learning evident process to know the students progress in learning assisted WhatsApp mobile tool. Besides, questionaires are also administered to students, both experimental and control groups to be filled, and then analyzed by the researcher for this study as the qualitative

\footnotetext{
${ }^{1}$ See, for example, Website of http:// learnenglishbritishcouncil.org/en/apps [accessed in Pontianak, West Kalimantan, Indonesia: July 10, 2019].
} 
data. R. Likert (1932) scale is also used to accumulate students responses (Likert, 1932; Carifio \& Perla, 2007; and Ozer \& Kilic, 2018). Table 3 is the reading rubric for some reading aspects assessed.

Meanwhile, the content of the topics and the tests are as follows: Firstly, Elephants Learn to Work Together: (1) What animals are experimented in this video?; (2) How are the animals in this experiment?; (3) How many attempts did they do till the reach the pail?; and (4) What did they want to get in the experiment?

Secondly, Why Do People Migrate: (1) Have you and your family ever moved to other province or other country?; (2) Why did you and your family move? Give your reasons!; (3) Give the reasons why do people move to other country?; and (4) How long will you adapt to your surrounding and why?

Thirdly, Ice Cream: (1) Do you like ice cream?; (2) When is the right time for having ice cream?; and (3) Please tell us the process how to make ice cream briefly!

Fourthly, ICT (Information and Communication Technology) in Learning: (1) Do you like studying using video or listening to teacher?; (2) Can we teach and send tasks to our students using smart phones?; (3) Mention some technological tools use in teaching learning process!; and (4) Have you ever discussed about your school tasks with friends or with your teacher using WhatsApp?

\section{FINDINGS AND DISCUSSION}

This section discusses the qualitative and quantitative data obtained from the questionaires; students' WhatsApp platforms; and the pre-test and post-test. The questionaires delivered consisted of questions about the usage of WhatsApp for students in learning, such as: "WhatsApp has helped me to improve my English language vocabulary"; "WhatsApp strengthened and gave me broader understanding of topics

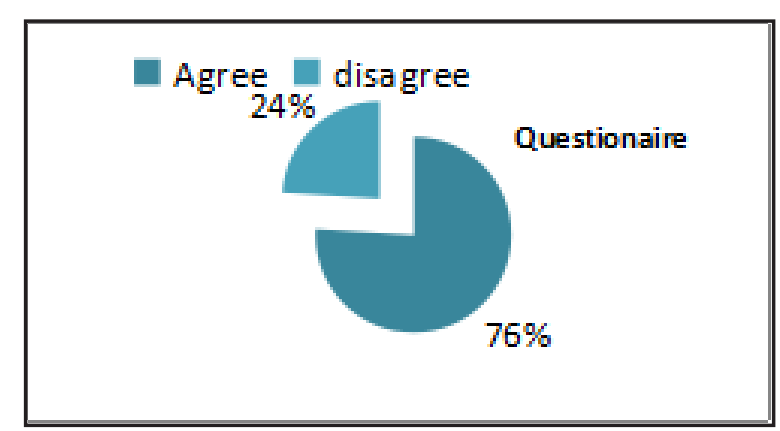

Diagram 1:

Questionaire

discussed in the classroom"; "Participating in English forum helped me improve my interaction in English than when I wouldn't participate"; and so forth.

The results of the questionaires delivered to students indicated that $76 \%$ students agree and feel convince with the WhatsApp implemented to support learning English, especially reading skill; otherwise, 24\% students disagree with WhatsApp implemented in learning English, especially reading skill, both using $\mathrm{R}$. Likert (1932) scale and others ( $c f$ Likert, 1932; Carifio \& Perla, 2007; and Ozer \& Kilic, 2018). Then, the results of the questionaires be accumulated and envisaged into the diagram 1.

As described in the diagram 1 that $76 \%$ students of class 2-C1 agree with the WhatsApp mobile learning implemented in learning reading, with some reasons that: WhatsApp mobile learning support and help them in learning reading; and even writing, especially with the new vocabularies used in reading text sent, then make them brave and encouraged to participate in discussion forum provided in WhatsApp platform, where students and lecturer may interact, as presented in WhatsApp platforms in the figures 2 and 3.

In the WhatsApp platforms provided in the figures 2 and 3 showed a limited interaction or discussion between some students and lecturer about the problem one student have and need help from others, and commented by the lecturer. Besides, just one 
or two students involved in the dialoque. The lecturer advices the students to discuss and talk in English in WhatsApp platform, and asked them about their tasks (the Elephant Learn to Work Together); why they didn't submit the tasks, then one students (Alip) replied that he couldn't do the task, because it was rather difficult for him; then, the lecturer answered that will be explained in the next meeting.

In the second WhatsApp platform, figure 3 , lecturer sent the new passage (Why Do People Migrate) and asked the students to finish the task as soon as possible; and some students responsed by saying: "Yes mam, on the way mam, yes mam". So, those are just some the example of WhatsApp platforms, which also as the data be considered in this study.

Some of the questions from the $1^{\text {st }}$ topic entitled "The Elephant Learn to Work Together" such as: "What animals are used in the experiment?"; "How are the elephants in the experiment?"; and "What are the goal of this experiment done?". Meanwhile, the questions for the $2^{\text {nd }}$ topic entitled "Why Do People Migrate", such as: "Have you and your family ever moved to other country or province?"; "Why did you and your family move? Give your own reasons!"; and "Give the reasons why do people move?". Those are some reasons and evident gained for the qualitative data of WhatsApp mobile learning implemented in learning English (cf Creswell, 2012; Amry, 2014; and Aspers \& Corte, 2019).

Next, $24 \%$ of the students disagree with WhatsApp applied as the assisted learning tool in teaching and learning English. Of course, there are some reasons followed, such as: "They didn't understand what the passage was, but shamed to ask to their friends or their lecturer"; "They were passive students, lazy, afraid to make mistakes"; and even "They are not ready with the technological advanced applied in education, such as the use of

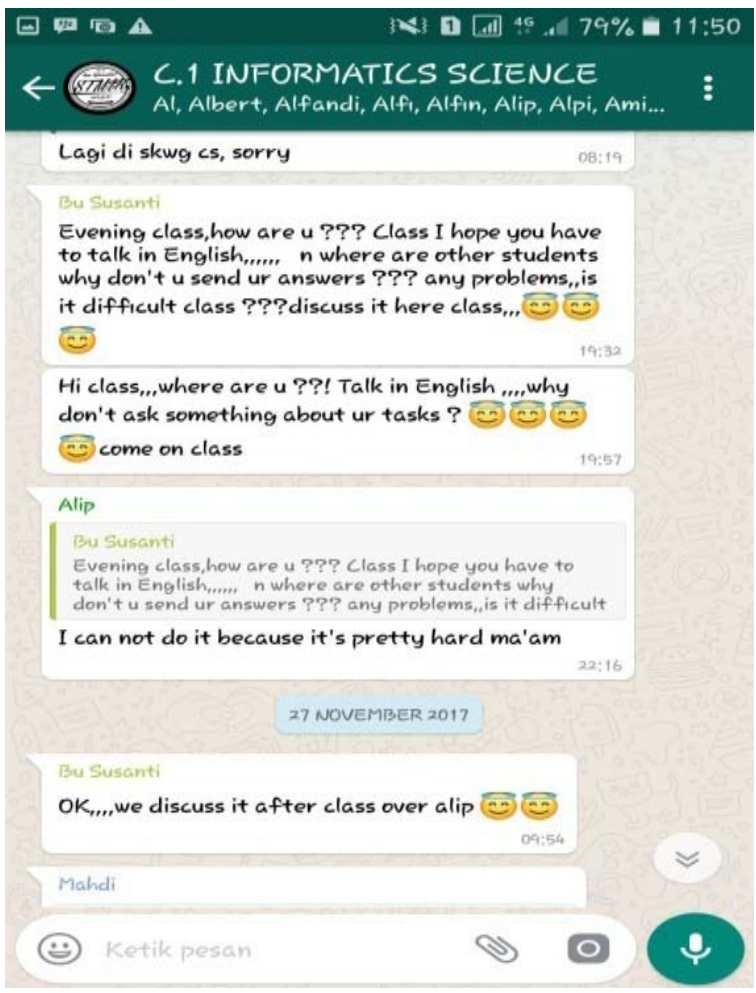

Figure 2:

WhatsApp Platform

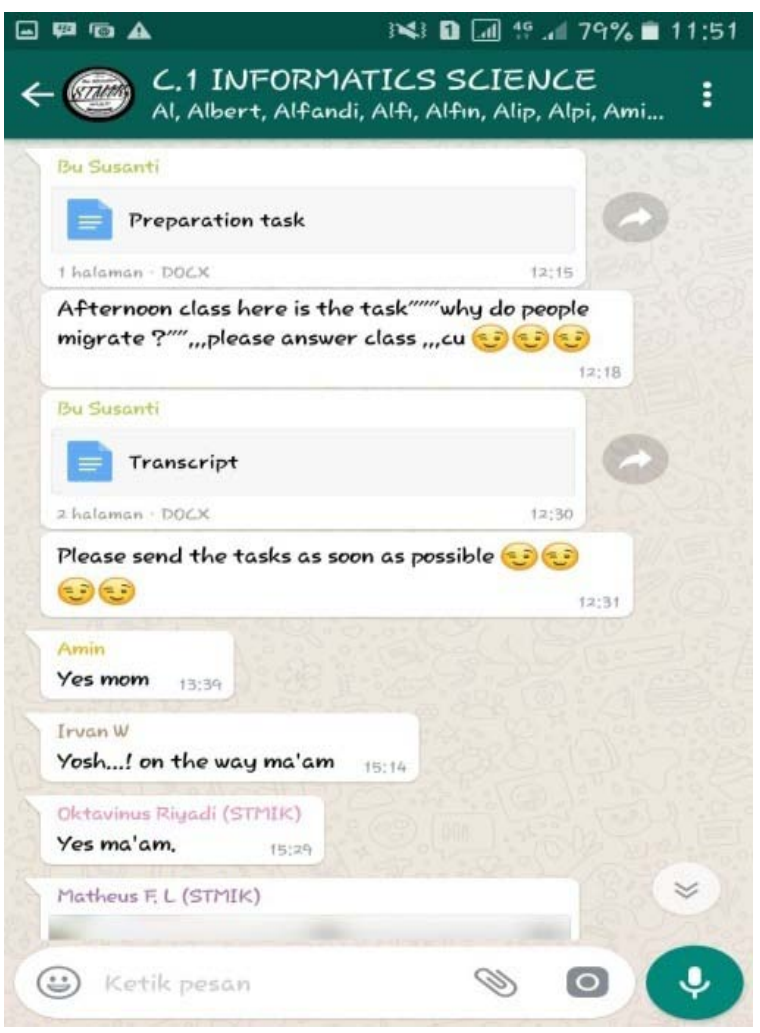

Figure 3:

WhatsApp Platform 
WhatsApp application to support teachinglearning process for formal and informal atmosphere" (cf Souriyavongsa et al., 2013; Echenique, 2014; and Alshammari, Parkes \& Adlington, 2017).

Then, from the questionaires delivered by STMIK (Sekolah Tinggi Manajemen Ilmu Komputer or College of Computer Science Management) institution in Pontianak, West Kalimantan, Indonesia to students, about their lecturer duty, found that some students said that they were not ready learning using mobile phones. They liked using the LCD (Liquid Crystal Display) only. In line with the fact found in this study, other WhatsApp limitation assisted learning is the absence of WiFi (Wireless Fidelity) connection, while learning at campus or at home; and they had to use their mobile data for the access of WhatsApp application, where speed of uploading was low to delayed of download material of learning ( $c f$ Echenique, 2014; Matlala, 2015; and Rawekar, 2017:24).

L. Cetinkaya (2017), and other scholars, added more also in research on social networks and the use of mobile devices, it was mentioned that students' untimely and unnecessary messages may cause distraction among students and their study process could get negatively effected (McCoy, 2013; Kuznekoff, Munz \& Titsworth, 2015; Cetinkaya, 2017; and Frisby et al., 2018).

The quantitative data obtained from this research is the results of pre-test and post-tests given to class before and after the lesson. The result of pre-test for control group is 48.8181 for control group and 49.8787 for the experimental group. It means that students' almost have the same English level capability for the research, as showed by the scores of standard deviation got that is 93.405 for control group and 95.197 for experimental group.

Furthermore, the post-test results show that for control group is 61.1818 and 62.7575 for the experimental group. And proved by the standard deviation as followed: 38.9972 for the control group and 19.153 for the experimental group. The scores gained for the pre-test and post-test than compared with the results of learning through WhatsApp learning tool, based on the scoring rubric above within several meeting. Nevertheless, the results of posttest is unsatisfied, but it is improving than before as delineated in table 2 .

Of course, there are some limitations happened of this failure in learning through WhatsApp assisted learning in this study, such as the limited frequency of studentslecturer interconnection via WhatsApp learning tool; limited students involved in WhatsApp dialoque; lack of discussion of topics between students and teachers and students and students (as shown in WhatsApp platform above); the limited WiFi connection at campus; untimely of messages sent may distract the students' concentration to lesson; students not ready yet with technological advanced in learning; and besides the problem of reading aspects itself, such as students still have the problem such as grammar, vocabulary, graphology, and content of the texts (cf Amry, 2014; Bouhnik \& Deshen, 2014; Susilo, 2014; Cetinkaya, 2017:12; and Gasaymeh, 2017).

They (students) still confuse to use the correct tenses in answering the questions given; the wrong vocabulary used; still cannot understand the questions given by giving the wrong answers in some tests; no comprehensive answers or lack of comprehension to the texts; and some are blanks (Muhsin, 2016; Atmojo, 2018; and Rohmatillah, 2018).

Discussion. This research showed insignificant results of WhatsApp assisted learning in learning English, especially reading skill to the STMIK (Sekolah Tinggi Manajemen Ilmu Komputer or College of Computer Science Management) students, class 2-C1 in Pontianak, West Kalimantan, Indonesia, as accumulated using of Means and Standard Deviation of Pre-Test and 
Post-Test. The data obtained through some instruments, such as questionnaires, WhatsApp platform, and pre-test and post-test.

The data from the questionnaires is the qualitative one showed that $76 \%$ students agree using WhatsApp assisted learning in learning reading skill, because they were assisted with the new vocabulary used in passages; and they were encouraged to involve in forum discussion, interact, discussed, and learned together anytime and anywhere in WhatsApp group, although the professional and interconnection frequency of students-lecturer is limited in WhatsApp mobile learning in this study. And 24\% students disagree with WhatsApp assisted learning in learning reading skill, because of some obstacles, such as they were passive, lazy, low internet access, unmotivated, and they were not ready with the technological advances in education, besides the reading problem itself as delineated into diagram 1 (cf Kheryadi, 2017; Bensalem, 2018; and Wijayanti \& Gunawan, 2018).

WhatsApp platform is also the qualitative data source for the research. As stated above, the more frequency of lecturerstudents interconnection influence students scores obtained in learning, the good or decent Wi-Fi (Wireless Fidelity) access must be available in campus or class to support the learning process, and more studies of WhatsApp assisted learning are needed in improving students' involvement and achievement in learning English, especially for reading skill for future study. Those facts with some reasons found in the study may answer the research questions stated before ( $f$ Kheryadi, 2017; Bakare \& Minah-Eeba, 2018; and Wijayanti \& Gunawan, 2018).

Although WhatsApp messenger is the best tool in creating the creative learning environment, it needs some precious considerations in learning atmosphere for fruitful outcomes. As stated by A.A. Alenazi (2017), and other scholars, it was found that integrating the use of WhatsApp in the learning environment does not automatically enhance pre-service teachers learning, rather WhatsApp needs to be used in certain conditions in order to yield the desired outcomes (Amry, 2014; Alenazi, 2017:6; and Wijayanti \& Gunawan, 2018).

Some barriers occurred, such as untypical usage of WhatsApp, negative peer pressure, issues with certain types of unbeneficial posts, lack of students interactions, etc. In this context, M.M. Hamad (2017), and other scholars, stated that, however, expenses involved in WhatsApp used; extra work load; distraction to learning; and lack of students' commitment for effective participation were identified as the greatest challenges of effective WhatsApp use for learning purposes. Besides, some other limitations are the absence WiFi connection within the campus college, also the only several meeting is not enough for conducting study using WhatsApp (Bouhnik \& Deshen, 2014; Hamad, 2017:85; Rawekar, 2017:24; and Wijayanti \& Gunawan, 2018).

Besides, the learning process is furthered by the teacher's guidance, the creation of supportive atmosphere, the creation of a learning community, and the sharing of knowledge and inspiring dialogue. Also the teacher should praise the students, initiate discussion, and use WhatsApp to confirm whether students do understand the topics or not, also to get to know students better (Willemse \& Bozalek, 2015; Rawekar, 2017; and Hanisi et al., 2018:33).

Lastly, as Dan Bouhnik \& Mor Deshen (2014) stated, and as cited also in A.L. Hanisi et al. (2018), that the advantages to the use of WhatsApp in teaching was the broad availability of the teacher to the students; the opportunity for students to help one another; and the opportunity for more in-depth acquaintance with the students on the educational and personal levels ( $c f$ Bouhnik \& Deshen, 2014; Echenique, 2014; and Hanisi et al., 2018:33). 


\section{CONCLUSION}

WhatsApp assisted learning is a recommended learning tool implemented in vary educational level to help learners to study anytime and anywhere using their smart phones recently. And more professional studies and experiences about WhatsApp assisted in learning is suggested to be conducted more in learning English to get the effective use of WhatsApp for the successful of learning, as well as the hindrances solution.

This study is far from perfect, so support, attention, and contribution from other professional researchers, teachers, also the campus or institution for the ease and decent WiFi (Wireless Fidelity) access is needed for the fruitful of learning using WhatsApp assisted mobile learning for our education. ${ }^{2}$

\section{References}

Ahmadi, Mohammad Reza. (2018). "The Use of Technology in English Language Learning: A Literature Review" in IJREE: International Journal of Research in English Education, Vol.3, No.2 [June], pp.115-125. Available online also at: http://ijreeonline.com/article-1-120-en. pdf [accessed in Pontianak, West Kalimantan, Indonesia: July 3, 2019].

Akhmad, Zulkifli \& Islan Nur Rizal Amiri. (2018). “Analysis of Students' Understanding in Using Formal and Informal Expression" in Journal al-Lisan, Vol.3, No.2 [Agustus], pp.94-103. Available online also at: https://media.neliti. com/media/publications/288897-analysisof-students-understanding-in-us-cdcb72a8. pdf [accessed in Pontianak, West Kalimantan, Indonesia: July 10, 2019].

Alenazi, A.A. (2017). "WhatsApp Messenger as a Learning Tool: An Investigation of Pre-Service Teachers' Learning without Instructor Presence" in Journal of Education and Training Studies,

\footnotetext{
${ }^{2}$ Statement: I, hereby, declare that this scientific article that I wrote, has never been submitted for publication in any other journals. In this article, there is no work or opinions that have been written or published in another person, except in writing clearly listed as the sources listed in the Bibliography or References. So, this article is really not product of plagiarism.
}

Volume 6.

Alfelaij, Bader Owied L.KH. (2015). “The Pedagogical Affordances of Smartphone Applications for Collaborative Learning (CL) amongst Pre-service Teachers in Kuwait". Unpublished Ph.D. Thesis. UK [United Kingdom]: The University of Exeter. Available online also at: https://ore.exeter.ac.uk/repository/ bitstream/handle/10871/21556/AlfelaijB. pdf [accessed in Pontianak, West Kalimantan, Indonesia: July 10, 2019].

Alshammari, R., M. Parkes \& R. Adlington. (2017). "Using WhatsApp in EFL Instruction with Saudi Arabian University Students" in Arab World English Journal, Volume 8(4). Available online also at: https://dx.doi.org/10.24093/ awej/vol8no4.5 accessed in Pontianak, West Kalimantan, Indonesia: July 27, 2019].

Amry, A.B. (2014). “The Impact of WhatsApp Mobile Social Learning on the Achievement and Attitudes of Female Students Compared with Face to Face Learning in the Classsroom" in European Scientist Journal, Volume 8, pp.117-132.

Aoumeur, Hayat. (2017). "The Impact of Class Size on Teaching and Learning English as a Foreign Language: The Case of the Department of English at Abdelhamid Ibn Badis University" in AWEJ: Arab World English Journal, Vol.8, No.2 [June], pp.349-361.

Arkorful, Valentina \& Nelly Abaidoo. (2014). "The Role of e-Learning, the Advantages, and Disadvantages of its Adoption in Higher Education" in International Journal of Education and Research, Vol.2, No.12 [December], pp.397410. Available online also at: https://www. ijern.com/journal/2014/December-2014/34. pdf [accessed in Pontianak, West Kalimantan, Indonesia: July 17, 2019].

Aspers, P. \& U. Corte. (2019). "What is Qualitative in Qualitative Research" in Qualitative Sociology, Volume 42(2), pp.139-160. Available online also at: https://www.ncbi.nlm.nih.gov/pmc/articles/ PMC6494783/ [accessed in Pontianak, West Kalimantan, Indonesia: January 17, 2020].

Atmojo, Arief Eko Priyo. (2018). "Students' Problems on S-V Agreement in TOEFL and Their Proposed Solutions" in LEKSEMA: Jurnal Bahasa dan Sastra, Vol.3, No.2 [Juli-Desember], pp.169-175.

Ayuningtyas, Pratika. (2018). "Whatsapp: Learning on the Go" in METATHESIS: Journal of English Language Literature and Teaching, Vol.2, No.2 [October], pp.159-170. Available online also at: http://jurnal.untidar.ac.id/index.php/metathesis/ article/view/629/722 [accessed in Pontianak, West Kalimantan, Indonesia: July 10, 2019]. 
Bakare, B.I. \& W. Minah-Eeba. (2018). “A Comprehensive Review of Wireless Fidelity (Wi-Fi) Technology in Nigeria" in IOSR Journal of Electronics and Communication Engineering (IOSR-JECE), Volume 13, Issue 3, Ver.II [MayJune], pp.37-42. Available online also at: http:// www.iosrjournals.org/iosr-jece/papers/Vol.\%20 13\%20Issue \%203/Version-2/F1303023742. pdf [accessed in Pontianak, West Kalimantan, Indonesia: August 1, 2019].

Barhoumi, Chokri. (2015). "The Effectiveness of WhatsApp Mobile Learning Activities Guided by Activity Theory on Students' Knowledge Management" in Contemporary Educational Technology, Volume 6(3), pp.221-238. Available online also at: https://files.eric.ed.gov/fulltext/ EJ1105764.pdf [accessed in Pontianak, West Kalimantan, Indonesia: July 10, 2019].

Beldarrain, Yoany. (2006). "Distance Education Trends: Integrating New Technologies to Foster Student Interaction and Collaboration" in Distance Education, Volume 27(2), pp.139-153.

Bensalem, Elias. (2018). "The Impact of WhatsApp on EFL students' Vocabulary Learning” in AWEJ: Arab World English Journal, Vol.9, No.1 [March], pp.23-38.

Bere, A. (2013). "Using Mobile Instant Messaging to Leverage Learner Participation and Transform Pedagogy at a South African University of Technology" in British Journal of Educational Technology, Volume 44(4), pp.544-561.

Bouhnik, Dan \& Mor Deshen. (2014). "WhatsApp Goes to School: Mobile Instant Messaging between Teachers and Students" in RESEARCH: Journal of Information Technology Education, Volume 13, pp.217-231. Available online also at: http://www.jite.org/documents/Vol13/ JITEv13ResearchP217-231Bouhnik0601. pdf [accessed in Pontianak, West Kalimantan, Indonesia: July 3, 2019].

Carifio, James \& Rocco J. Perla. (2007). “Ten Common Misunderstandings, Misconceptions, Persistent Myths, and Urban Legends about Likert Scales and Likert Response Formats and Their Antidotes" in Journal of Social Sciences, Volume 3(3), pp.106-116.

Cetinkaya, L. (2017). "The Impact of WhatsApp Use on Success in Education Process" in International Review of Research in Open and Distributed Learning, Volume 12.

Chawinga, W.D. (2017). "Taking Social Media to a University Classroom: Teaching and Learning Using Twitter and Blogs" in International Journal of Educational Technology in Higher Education, Volume 14. Available online also at: https://educationaltechnologyjournal. springeropen.com/articles/10.1186/s41239017-0041-6 [accessed in Pontianak, West Kalimantan, Indonesia: July 17, 2019].

Chinnery, G. (2006). "Going to the MALL: Mobile Assisted Language Learning" in Language Learning \& Technology, Volume 10(1), pp.9-16.

Church, K. \& R. de Oliveira. (2013). "What's Up with WhatsApp? Comparing Mobile Instant Messaging Behaviors with Traditional SMS" in Proceedings of the $15^{\text {th }}$ International Conference on Human-Computer Interaction with Mobile Devices and Services, pp.352-361.

Creswell, J.W. (2012). Educational Research: Planning, Conducting, and Evaluating Quantitative and Qualitative Research. Boston: Pearson Education.

Darling-Hammond, Linda et al. (2019). "Implications for educational practice of the science of learning and development" in Journal of Applied Developmental Science, Volume 24, Issue 2 [February], pp.97-140. Available online also at: https://doi.org/10.1080/10888691.2018.15377 91 [accessed in Pontianak, West Kalimantan, Indonesia: January 15, 2020].

Deshen, D.B. et al. (2014). "WhatsApp Goes to School: Mobile Instant Messaging between Teachers \& Students" in Journal of Information Technology Education Research, Volume 2, pp.219-228.

Eady, M.J. \& L. Lockyer. (2013). “Tools for Learning: Technology and Teaching Strategies" in Learning to Teach in the Primary School, No.71, published by Queensland University of Technology, Australia. Available online also at: https://ro.uow. edu.au/cgi/viewcontent.cgi?article $=1413 \&$ conte

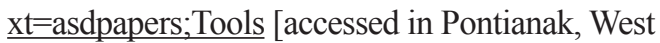
Kalimantan, Indonesia: July 3, 2019].

Echenique, Eliana Esther Gallardo. (2014). “An Investigation of the Social and Academic Uses of Digital Technology by University Students". Unpublished Doctoral Thesis. Tarragona: Department of Pedagogy, Universitat Rovirai Virgili. Available online also at: https://www. tesisenred.net/bitstream/handle/10803/277423/ Thesis_EG_final.pdf [accessed in Pontianak, West Kalimantan, Indonesia: July 27, 2019].

Faizi, Rdouan, Abdellatif el-Afia \& Raddouane Chiheb. (2013). "Exploring the Potential Benefits of Using Social Media in Education" in iJEP, Volume 3, Issue 4 [October], pp.50-53.

Fattah, S.F. (2015). "The Effectiveness of Using WhatsApp Messenger as One of Mobile Learning Techniques to Develop Students' Writing Skill" in Journal of Education and Practice, Volume 8, pp.117-126.

Felix, R., P.A. Rauschnabel \& C. Hinsch. (2016). 
"Elements of Strategic Social Media Marketing: A Holistic Framework" in Journal of Business Research, Volume 70, pp.118-126.

Frisby, Brandi N. et al. (2018). "Peers and Instructors as Sources of Distraction from a Cognitive Load Perspective" in International Journal for the Scholarship of Teaching and Learning, Vol.12, No.2, Article 6. Available online also at: https:// doi.org/10.20429/ijsotl.2018.120206 [accessed in Pontianak, West Kalimantan, Indonesia: July 27, 2019].

Gasaymeh, Al-Mothana M. (2017). "University Students' use of Whatsapp and their Perceptions Regarding its Possible Integration into their Education" in Global Journal of Computer Science and Technology: G Interdisciplinary, Volume 17, Issue 1. Available online also at: https://globaljournals.org/GJCST_Volume17/1University-Students-use-of-Whatsapp.pdf [accessed in Pontianak, West Kalimantan, Indonesia: July 17, 2019].

Gon, Sonia \& Alka Rawekar. (2017). "Effectivity of E-Learning through Whatsapp as a Teaching Learning Tool" in MVP Journal of Medical Sciences, Volume 4(1), January-June, pp.19-25.

Hamad, M.M. (2017). "Using WhatsApp to Enhance Students' Learning of English Language Experience to Share" in Higher Education Studies, Volume 85. Available online also at: http://leanenglish [accessed in Pontianak, West Kalimantan, Indonesia: July 24, 2019].

Hanisi, A.L. et al. (2018). "The Use of WhatsApp in Collaborative Learning to Improve English Teaching and Learning Process" in International Journal of Research Studies in Educational Technology, Volume 3, pp.29-42.

Honeyman, M. \& G. Miller. (1993). “Agriculture Distance Education: A Valid Alternative for Higher Education?" in Proceedings of the $20^{\text {th }}$ Annual National Agricultural Education Research Meeting, pp.67-73.

Ifenthaler, D. \& V. Schweinbenz. (2016). "Students' Acceptance of Tablet PCs in the Classroom" in Journal of Research on Technology in Education, Volume 48(4), pp.306-321.

Isaac, Mike. (2019). "Zuckerberg Plans to Integrate WhatsApp, Instagram, and Facebook Messenger" in The New York Times, on June 25. Available online also at: https://www.nytimes. com/2019/01/25/technology/facebook-instagramwhatsapp-messenger.html [accessed in Pontianak, West Kalimantan, Indonesia: January 17, 2020].

Kelly, T. \& M. Minges. (2011). "South Sudan: ICT Sector Background". Paper prepared for South Sudan Donor Coordination Conference, in Washington D,C., on December.
Kheryadi. (2017). "The Implementation of WhatsApp as a Media of English Language Teaching" in LOQUEN, Vol.10, No.2 [July-December], pp.1-13. Available online also at: https://media. neliti.com/media/publications/237570-theimplementation-of-whatsapp-as-a-medi-f6caeb29. pdf [accessed in Pontianak, West Kalimantan, Indonesia: August 1, 2019].

Kilfoil, W.R. [ed]. (2015). Moving Beyond the Hype: A Contextualised View of Learning with Technology in Higher Education. Pretoria: Universities South Africa. Available online also at: http://www.usaf.ac.za/wp-content/ uploads/2017/03/Moving-beyond-the-hypeA-contextual-view-of-learning-technology-inHE Nov-2015.pdf [accessed in Pontianak, West Kalimantan, Indonesia: July 17, 2019].

Knight, K.L. (2010). "Study/Experimental/Research Design: Much More than Statistics" in JAT: Journal of Athletic Training, Volume 45(1), January-February, pp.98-100. Available online also at: https://www.ncbi.nlm.nih.gov/pmc/ articles/PMC2808761/ [accessed in Pontianak, West Kalimantan, Indonesia: July 20, 2019].

Kolzow, David R. (2014). "Leading from Within: Building Organizational Leadership Capacity". Available online at: https://www.iedconline. org/clientuploads/Downloads/edrp/Leading from Within.pdf [accessed in Pontianak, West Kalimantan, Indonesia: July 10, 2019].

Kuznekoff, J.H., S. Munz \& S. Titsworth. (2015). "Mobile Phones in the Classroom: Examining the Effects of Texting, Twitter, and Message Content on Student Learning" in Communication Education Online, pp.1-22. doi:10.1080/0363452 3.2015.1038727.

Lediga, Mamaroba Sylvia. (2017). "The Use of Handheld Mobile Devices: An Exploratory Study of English Language Student Educators". Unpublished M.A. Thesis. South Africa: Faculty of Humanities, School of Languages and Communication Studies, the University of Limpopo. Available online also at: http:// ulspace.ul.ac.za/bitstream/handle/10386/2204/ lediga_ms_2018.pdf [accessed in Pontianak, West Kalimantan, Indonesia: July 17, 2019].

Likert, R. (1932). “A Technique for the Measurement of Attitudes" in Archives of Psychology, Volume 140, pp.1-55.

Long, Daniel W. (2018). “Exploring Generational Differences in Text Messaging Usage and Habits". Unpublished Ph.D. Dissertation. Florida: College of Engineering and Computing NSU [Nova Southeastern University]. Available online also at: https://nsuworks.nova.edu/cgi/ viewcontent.cgi? article $=2054 \&$ context $=$ gscis etd 
[accessed in Pontianak, West Kalimantan, Indonesia: July 3, 2019].

Matlala, Mpubane Emanuel. (2015). "The Use of the Internet by Grade 11 Learners from Selected Schools in the Sekhukhune District, Makhuduthamaga Local Municipality in Limpopo Province". Unpublished Master's Thesis. Pietermaritzburg: School of Social Sciences, College of Humanities, University of KwaZuluNatal. Available online also at: https://pdfs. semanticscholar.org/7c82/27cf658ec4b4883385 0ff42e5f320020d43a.pdf [accessed in Pontianak, West Kalimantan, Indonesia: July 27, 2019].

McCoy, B.R. (2013). "Digital Distractions in the Classroom: Student Classroom Use of Digital Devices for Non-Class Related Purposes" in Journal of Media Education, Volume 4, pp.5-14.

Mhandeni, J.W. (2016). "WhatsApp Mobile Tools in Second Language Learning: Opportunities, Potentials, and Chalenges in Higher Education Settings in Tanzania" in International Journal of English Language Education, Volume 7, pp.71-74.

Minalla, Amir Abdalla. (2018). "The Effect of WhatsApp Chat Group in Enhancing EFL Learners' Verbal Interaction Outside Classroom Contexts" in English Language Teaching, Vol.11, No.3, pp.1-7. Available online also at: https://files.eric.ed.gov/ fulltext/EJ1169997.pdf [accessed in Pontianak, West Kalimantan, Indonesia: July 21, 2019].

Motteram, G. (2013). Innovation in Learning Technology for English Language Teaching. London: British Council.

Muhsin, Muh Arief. (2016). "Analysing the Students Errors in Using Simple Present: A Case Study at Junior High School in Makassar" in Pacific Science Review B: Humanities and Social Sciences, Volume 2, Issue 3 [November], pp.81-87. Available online also at: https:// www.sciencedirect.com/science/article/pii/

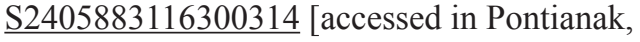
West Kalimantan, Indonesia: July 27, 2019].

Onat-Stelma, Z., D. Slaouti \& G. Motteram. (2013). "Technology and Adult Language Teaching" in Innovations in Learning Technologies for English Language Teaching. London: British Council, pp.67-86.

Onwuegbuzie, Anthony J. \& Julie P. Combs. (2011). "Data Analysis in Mixed Research: A Primer" in International Journal of Education, Vol.3, No.1, pp.1-25. Available online also at: http://www. macrothink.org/journal/index.php/ije/article/ viewFile/618/550 [accessed in Pontianak, West Kalimantan, Indonesia: July 21, 2019].

Ozer, Omer \& Figen Kilic. (2018). “The Effect of Mobile-Assisted Language Learning Environment on EFL Students' Academic
Achievement, Cognitive Load, and Acceptance of Mobile Learning Tools" in EURASIA Journal of Mathematics, Science, and Technology Education, Volume 14(7), pp.2915-2928. Available online also at: https://www.ejmste.com/ download/the-effect-of-mobile-assisted-languagelearning-environment-on-efl-students-academicachievement-5481.pdf [accessed in Pontianak, West Kalimantan, Indonesia: July 10, 2019].

Pandiya. (2013). "Rubrics on Scoring English Test for Four Language Skills" in RAGAM: Jurnal Pengembangan Humaniora, Volume 48.

Pim, Chris. (2013). "Emerging Technologies, Emerging Minds: Digital Innovations within the Primary Sector" in Gary Motteram [ed]. Innovations in Learning Technologies for English Language Teaching. London: British Council, pp.15-42. Available online also at: https://www.teachingenglish.org.uk/sites/ teacheng/files/C607\%20Information $\% 20$ and $\% 20$ Communication_WEB\%20ONLY_FINAL. pdf [accessed in Pontianak, West Kalimantan, Indonesia: July 10, 2019].

Prensky, M. (2001). "Digital Natives: Digital Immigrants, Part 1" in On the Horizon, Volume 9(5), pp.1-6. Published by MBC University Press.

Rambe, P. \& C. Chipunza. (2013). "Using Mobile Devices to Leverage Student Access to Collaboratively Generated Resources: A Case of WhatsApp Instant Messaging at a South African University". Paper for International Conference on Advanced ICT and Education.

Rawekar, S.G. (2017). "Effectivity of e-Learning through WhatsApp as a Teaching Learning Tool" in MVP Journal of Medical Sciences, Volume 9, pp.19-24.

Rohmatillah. (2018). “A Study on Students' Difficulties in Learning Vocabulary". Available online at: https:// media.neliti.com/media/publications/178083-ENnone.pdf [accessed in Pontianak, West Kalimantan, Indonesia: July 27, 2019].

Roman, D.N. (2016). "WhatsApp Messaging: Achievement and Success in Academia" in International Journal of Higher Education, Vol.5, No.4, pp.255-264.

Sam, P. (2016). "Learning Beyond the Classroom through WhatsApp: An Informal Channel to Motivate Learners to Stay Connected" in Asian Journal of Research in Social Sciences and Humanities, Volume 18, pp.31-42.

Souriyavongsa, Thongma et al. (2013). "Factors Causes Students Low English Language Learning: A Case Study in the National University of Laos" in International Journal of English Language Education, Vol.1, No.1, pp.179-192. Available online also at: http://dx.doi.org/10.5296/ 
ijele.v1i1.3100 [accessed in Pontianak, West Kalimantan, Indonesia: July 20, 2019].

Sung, Y.T., K.E. Chang \& T.C. Liu. (2016). "The Effects of Integrating Mobile Devices with Teaching and Learning on Students' Learning Performance: A Meta-Analysis and Research Synthesis" in Computers \& Education, Volume 94 [March], pp.252-275. Available online also at: https://doi.org/10.1016/j.compedu.2015.11.008 [accessed in Pontianak, West Kalimantan, Indonesia: July 20, 2019].

Susilo, A. (2014). "Exploring Facebook and WhatsApp as Supporting Social Network Applications for English Learning in Higher Education" in Journal of Open University Malaysia, Volume 5, pp.17-22.

Ta'ammeh, M.A. (2017). "The Effect of Using WhatsApp Messenger in Learning English Language among University Students" in Center for Promoting Education and Research, Volume 5, pp.15-22.

Tzuk, A. (2013). “WhatsApp Has Reached 350 Million Active Users Per Month" in Calcalist, on 23 October. Available online also at: http://www. calcalist.co.il/internet/articles/0,7340,L-3615097,00. $\underline{\mathrm{html}}$ [accessed in Pontianak, West Kalimantan, Indonesia: July 3, 2019].

Wardani, Ika \& Djukri. (2019). "Teaching Science Process Skill Using Guided Inquiry Model with Starter Experiment Approach: An Experimental Study" in JPBI: Jurnal Pendidikan Biologi Indonesia, Vol.5, No.2 [July], pp.277-284.

Website of http://learnenglishbritishcouncil.org/en/ apps [accessed in Pontianak, West Kalimantan, Indonesia: July 10, 2019].
Wijayanti, Anita \& Yohanes Bambang Gunawan. (2018). "Students' Perceptions towards the Utilization of WhatsApp for Vocabulary Teaching and Learning" in ADJES: Ahmad Dahlan Journal of English Studies, Vol.5, No.2 [September], pp.78-91.

Willemse, J.J. \& V. Bozalek. (2015). "Exploration of the Affordances of Mobile Devices in Integrating Theory and Clinical Practice in an Undergraduate Nursing Programme" in CURATIONIS, Volume 38(2), September. Available online also at: https://www.ncbi.nlm.nih.gov/pmc/articles/ PMC6091599/ [accessed in Pontianak, West Kalimantan, Indonesia: July 3, 2019].

Yudhiantara, Rully Agung \& Ihsan Abdul Nasir. (2017). "Toward Mobile-Assisted Language Learning (MALL): Reaping Mobile Phone Benefits in Classroom Activities" in REGISTER: Language \& Language Teaching Journals, Vol.10, No.1, pp.12-28. Available online also at: https://media.neliti.com/media/ publications/177351-EN-toward-mobile-assistedlanguage-learning.pdf [accessed in Pontianak, West Kalimantan, Indonesia: July 3, 2019].

Zengin, B., A. Arikan \& D. Dogan. (2011). "Opinions of English Major Students about Their Departments' Websites" in Contemporary Educational Technology, Volume 2(4), pp.294-307.

Zuo, Wei. (2017). "Teachers' Role in Dealing with Errors in Students' Second Language Learning" in Theory and Practice in Language Studies, Vol.7, No.8 [August], pp.644-650. Available online also at: https://www.academypublication. com/ojs/index.php/tpls/article/viewFile/ tpls0708644650/1199 [accessed in Pontianak, West Kalimantan, Indonesia: July 10, 2019]. 
SUSANTI,

The Use of WhatsApp

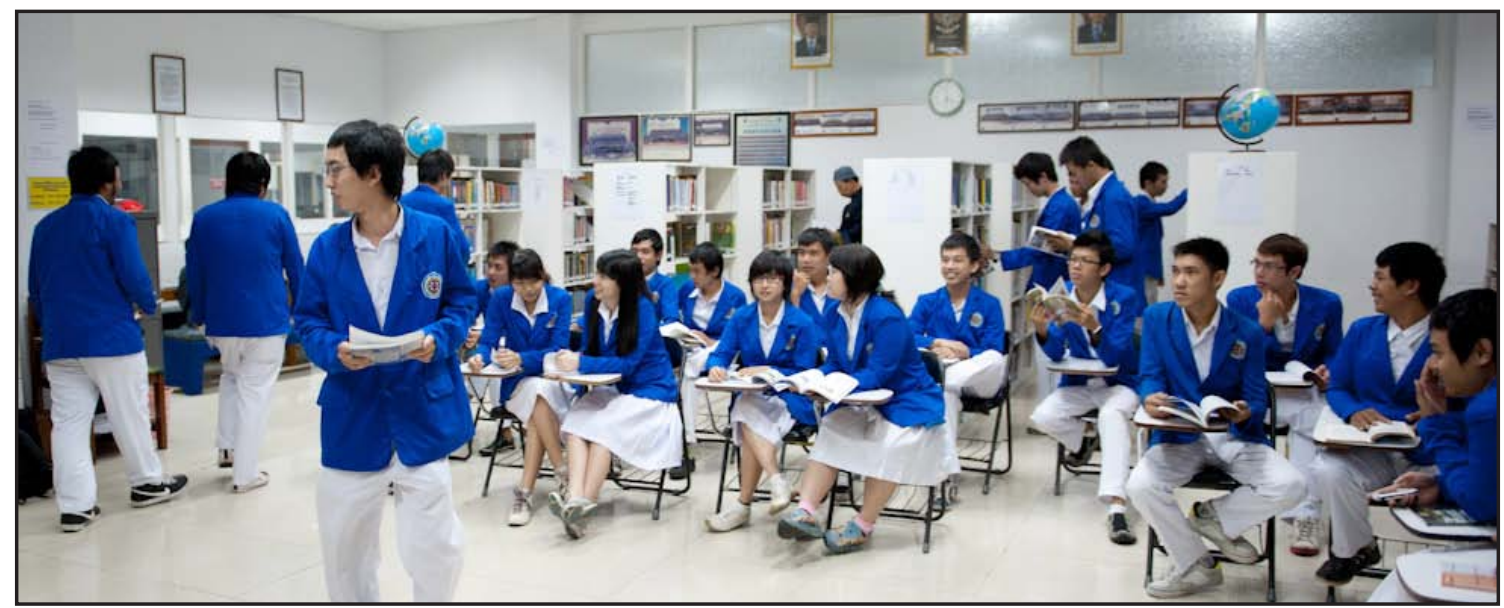

Students of STMIK Pontianak, West Kalimantan, Indonesia

(Source: https://www.stmikpontianak.ac.id, 1/8/2019)

WhatsApp assisted learning is a recommended learning tool implemented in vary educational level to help learners to study anytime and anywhere using their smart phones recently. And more professional studies and experiences about WhatsApp assisted in learning is suggested to be conducted more in learning English to get the effective use of WhatsApp for the successful of learning, as well as the hindrances solution. 